\title{
ETHzürich
}

\section{In Situ Heavy Metal Accumulation in Lettuce Growing Near a Former Mining Waste Disposal Area Implications for Agricultural Management}

\author{
Journal Article \\ Author(s): \\ Conesa, Héctor M.; Pérez-Chacón, Jose A.; Arnaldos, Raquel; Moreno-Caselles, Joaquín; Faz-Cano, Ángel \\ Publication date: \\ 2010 \\ Permanent link: \\ https://doi.org/10.3929/ethz-b-000028730
}

Rights / license:

In Copyright - Non-Commercial Use Permitted

Originally published in:

Water, Air, \& Soil Pollution 208(1-4), https://doi.org/10.1007/s11270-009-0173-y 


\title{
In Situ Heavy Metal Accumulation in Lettuce Growing Near a Former Mining Waste Disposal Area: Implications for Agricultural Management
}

\author{
Héctor M. Conesa • Jose A. Pérez-Chacón • \\ Raquel Arnaldos • Joaquín Moreno-Caselles • \\ Ángel Faz-Cano
}

Received: 28 April 2009 /Accepted: 23 July 2009/Published online: 30 August 2009

(C) Springer Science + Business Media B.V. 2009

\begin{abstract}
Mining wastes may pose risk nearby urban and agricultural areas. We investigated a lettuce crop land close to a former capped mine tailing in order to determinate the metal uptake by crops. Soil plot sampling design within the crop area and two transects along the tailing were performed. In addition, lettuces (root and leaves) were analyzed after transplant and harvest. The results showed a $\mathrm{pH}$ of around 7-8 for all the soil samples. Total metal concentrations were as follows: $190-510 \mathrm{mg} \mathrm{kg}^{-1} \mathrm{~Pb}$, 13-21 $\mathrm{mg} \mathrm{kg}^{-1} \mathrm{Cu}$, and $210-910 \mathrm{mg} \mathrm{kg}^{-1} \mathrm{Zn}$. Diethylene triamine pentaacetic acid-extractable $\mathrm{Pb}$
\end{abstract}

H. M. Conesa $(\bowtie) \cdot J$. A. Pérez-Chacón · R. Arnaldos •

Á. Faz-Cano

Área de Edafología y Química Agrícola,

Departamento de Ciencia y Tecnología Agraria,

Universidad Politécnica de Cartagena,

Paseo Alfonso XIII,

52-30203 Cartagena, Spain

e-mail: hector.conesa@env.ethz.ch

J. Moreno-Caselles

Área de Edafología y Química Agrícola,

Departamento de Agroquímica y Medio Amiente,

Universidad Miguel Hernández,

Orihuela, Spain

Present Address:

H. M. Conesa

Soil Protection Group, Institute of Terrestrial Ecosystems,

Swiss Federal Institute of Technology, ETH Zürich,

Universitätstrasse 16,

8092 Zürich, Switzerland was around $18 \%$ of the total $\mathrm{Pb}$ in some samples. Transects along the base and on the plateau of the tailing showed high metal concentrations of $\mathrm{Pb}$ (up to $5,800 \mathrm{mg} \mathrm{kg}^{-1}$ ) and $\mathrm{Zn}$ (up to $4,500 \mathrm{mg} \mathrm{kg}^{-1}$ ), indicating that capping layer had been eroded. Lettuce leaves showed $\mathrm{Pb}$ concentrations within standard for human health $\left(<0.3 \mathrm{mg} \mathrm{kg}^{-1}\right.$ in fresh weight). For essential micronutrients such as $\mathrm{Cu}$ and $\mathrm{Zn}$, leaves had optimal content $\left(10-28 \mathrm{mg} \mathrm{kg}^{-1} \mathrm{Cu}\right.$, 60-85 mg kg-1 $\mathrm{Zn})$. A continued monitoring in metal uptake is needed in crop lands close to mining wastes in order to prevent risks in food safety. Capped tailings must be monitored and rehabilitation works performed from time to time.

Keywords Mine tailings $\cdot$ Lettuce $\cdot$ Metals .

Biofortification

\section{Introduction}

Former mining areas are frequently the sources of environmental problems even many years after the definitive closure of the mining operations. The negative impacts of these mining activities on the surroundings is mainly due to the presence of tailings, which are usually characterized by low $\mathrm{pHs}$, high concentration of heavy metals, lack of nutrients, low water retention capacity, high electrical conductivity, and high slopes (Ernst 1996; Conesa et al. 2006). These factors inhibit plant establishment and, consequently, 
their surfaces are exposed to wind and water erosion, which may result in the contamination of nearby waters and soils with toxic metals (Salomons 1995). Capping tailings with nonpolluted materials results a provisional option to decrease the release and spread of metals to the surroundings. However, total safety has been shown to be difficult to achieve (Conesa et al. 2006). There are many cases of metal pollution in agricultural lands nearby mining areas worldwide (Alloway et al. 1998; Leita et al. 1998). In most of cases, the levels of metal uptake by crops are supposed to be an important risk for human health (Lee and Chon 2003).

The Cartagena-La Union Mining District (0-400 m above sea level; $37^{\circ} 37^{\prime} 20^{\prime \prime} \mathrm{N}, 0^{\circ} 50^{\prime} 55^{\prime \prime} \mathrm{W}-37^{\circ} 40^{\prime} 03^{\prime \prime}$ $\left.\mathrm{N}, 0^{\circ} 48^{\prime} 12^{\prime \prime} \mathrm{W}\right)$ is located on the southeast of the Iberian Peninsula (Fig. 1) and covers an area of $50 \mathrm{~km}^{2}$. The area is characterized by a semiarid Mediterranean climate. The annual rainfall averages $275 \mathrm{~mm}$ and mainly falls during spring and autumn. The annual average temperature is $17^{\circ} \mathrm{C}$ and the annual evapotranspiration rate is $857 \mathrm{~mm}$. The Cartagena-La Union Mining District was an important mining area for more than 2,500 years. Mining activity finally ceased in 1991. Base metals were smelted from sulfide minerals that included galena and sphalerite. Until 1955, mine wastes were dumped into local streams. Thereafter, waste was left on the ground forming tailings. Nowadays, there are reported 48 mine tailings which cover approximately 160 ha in the Cartagena-La Union area (Martínez-Orozco et al. 1993). The tailings are usually close to urban and agricultural areas, increasing the risk of metal exposure to humans via wind-borne dust or affecting plant productivity and food safety. Some of these tailings have been restored by capping with nonpolluted material. However, the short intensive rainfalls, typical of this climate, and wind have affected the former restoration works posing in risk nearby agricultural areas (Conesa et al. 2006). Some works under controlled lab conditions have been performed in this area in relation to food safety (Conesa et al. 2009) but still conducting studies at field conditions is lacking.

The objective of this work was to study the metal uptake in a lettuce crop land close to a previously capped tailing. At the same time, we investigated the tailing surface in order to check the current state of the former capping layer.

\section{Material and Methods}

\subsection{Sampling Description}

Sampling was conducted in an agricultural area located near La Union town (Fig. 1). In this area, lettuces are a common crop (Lactuca sativa var. capitata). The site is close to a tailing which was capped with nonpolluted material and revegetated 20 years ago (Fig. 2). Within the crop area, four plots of $5 \times 5 \mathrm{~m}^{2}$ were performed and nine soil samples were taken within each plot from the first $25 \mathrm{~cm}$ in randomize distributed points. In addition, two transects were performed along the basis of the tailing (transect 2) and on the plateau (transect 1). We sampled three lettuces in each plot at two different times of the growth: a week after transplant and during harvest (fifth week).

\subsection{Soil Analyses}

Soil $\mathrm{pH}$ was determined in 1:1 water:soil and $1 \mathrm{~N}$ $\mathrm{KCl}$ :soil ratios using a Crison Basic $20 \mathrm{pH}$ meter. Electrical conductivity of the saturated extract was measured using a conductivimeter Crison Micro CM 2200. Equivalent calcium carbonate was determined using Bernard calcimeter. The texture was determined using the Robinson pipette method combined with sieving. The method of Chapman (1965) was followed in order to determine the cation exchange capacity. Organic carbon was determined by the oxidation of organic matter using potassium dichromate. Total nitrogen was determined using the Kjeldahl method (Duchaufour 1970). Total $\mathrm{Cu}, \mathrm{Pb}$, and $\mathrm{Zn}$ concentrations were determined by digesting $1 \mathrm{~g}$ of ground soil in $10 \mathrm{ml}$ of a solution $1: 1 \mathrm{HNO}_{3} / \mathrm{HClO}_{4}$ at $210^{\circ} \mathrm{C}$ during $1.5 \mathrm{~h}$. The resulting extracts were diluted to $25 \mathrm{ml}$ with deionized water and then filtered through filter paper Albet $\mathrm{N}^{\circ} 242$. The bioavailable metals were determined using a reagent solution containing $0.005 \mathrm{M}$ diethylene triamine pentaacetic acid (DTPA), $0.01 \mathrm{M} \mathrm{CaCl}_{2}$, and $0.1 \mathrm{M}$ triethanolamine (Lindsay and Norvell 1978) in 1:2 soil/DTPA solution that was shaken for $2 \mathrm{~h}$ and then filtered through filter paper Albet $\mathrm{N}^{\circ}$ 2442. All the resulting extracts were measured using flame atomic absorption spectroscopy (UNICAM 969 AA spectrometer). The methodology for total metal concentration in soil was referenced using the CRM027-050 Certified Material (Resource 
Fig. 1 Location of the studied area

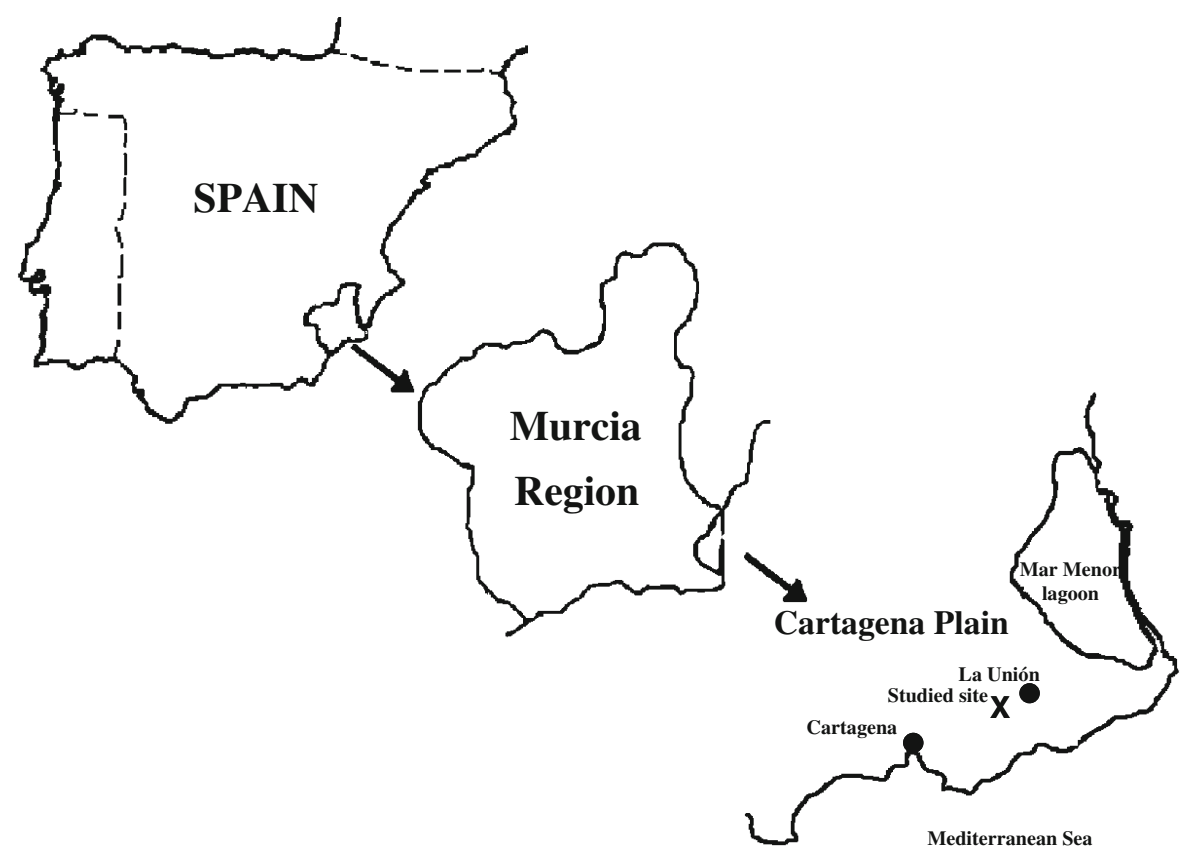

Technology Corporation, USA). We obtained recoveries of $112 \%$ for $\mathrm{Cu}, 99 \%$ for $\mathrm{Zn}$, and $94 \%$ for $\mathrm{Pb}$.

\subsection{Plant Analyses}

For each single sample, roots and leaves were carefully washed with distilled water and then dried at $65^{\circ} \mathrm{C}$ for $72 \mathrm{~h}$. The dried samples were ground using a mill Janke \& Kunkel IKA ${ }^{\circledR}$ Labortechnik A-10. For each sample, $0.4 \mathrm{~g}$ was incinerated prior to a metal digestion in

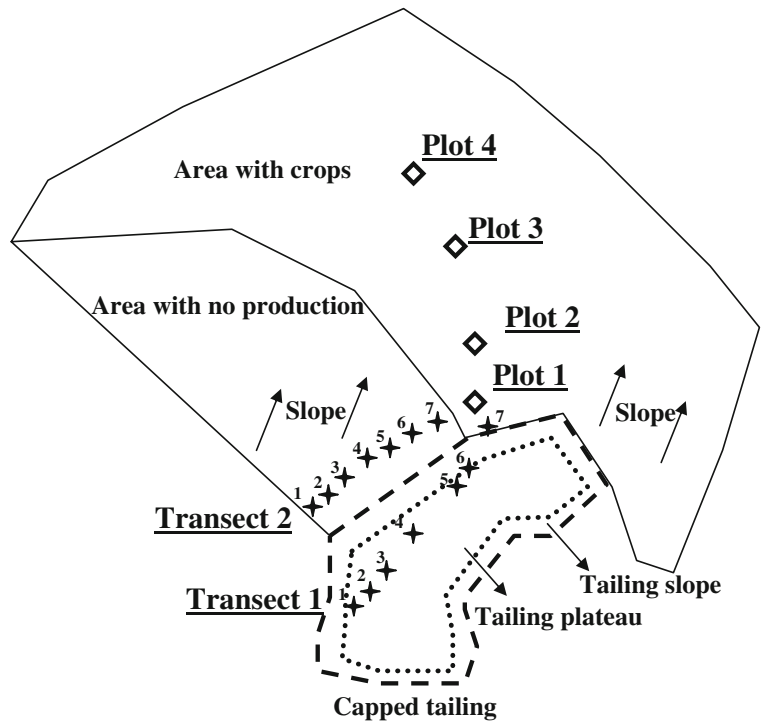

Fig. 2 Basic scheme of the sampling protocol
$10 \mathrm{ml}$ of a solution $1: 1 \mathrm{HNO}_{3} / \mathrm{HClO}_{4}$ at $210^{\circ} \mathrm{C}$ during $1.5 \mathrm{~h}$. The resulting extracts were diluted to $25 \mathrm{ml}$ with deionized water and then filtered through filter paper Albet $\mathrm{N}^{\circ}$ 242. Solution concentrations were measured using flame atomic absorption spectroscopy (UNICAM 969 AA spectrometer).

\section{Results and Discussion}

\subsection{Soil Characteristics}

\subsubsection{Soil Plots}

Analyses of soil properties are shown in Table 1. According to $\mathrm{pH}$ values, the soils were classified from slightly to moderately alkaline. Electrical conductivity showed values between 3.4 and $4.8 \mathrm{dS} \mathrm{m}^{-1}$ indicating a moderate salt content. This may be due to the use of saline groundwater for irrigation. The rest of the parameters seem to be in the same range as undisturbed soils in the area (Conesa 2003).

Soils from the nearby Cartagena plain (Fig. 1) have geochemical backgrounds of $12.6 \mathrm{mg} \mathrm{kg}^{-1} \mathrm{Cu}$, $9 \mathrm{mg} \mathrm{kg}^{-1} \mathrm{~Pb}$, and $41 \mathrm{mg} \mathrm{kg}^{-1} \mathrm{Zn}$. The thresholds to be followed in determining soil contamination in the aforementioned area are settled in $30 \mathrm{mg} \mathrm{kg}^{-1} \mathrm{Cu}$, $57 \mathrm{mg} \mathrm{kg}^{-1} \mathrm{~Pb}$, and $90 \mathrm{mg} \mathrm{kg}^{-1} \mathrm{Zn}$ (MartínezSánchez and Pérez-Sirvent 2007). However, these 
Table 1 Soil plot analyses

\begin{tabular}{lllllllllll}
\hline Soil samples & $\mathrm{pH} \mathrm{H} \mathrm{H}_{2}$ & $\mathrm{pH} \mathrm{KCl}$ & $\begin{array}{l}\mathrm{EC} \\
\left(\mathrm{dS} \mathrm{m}{ }^{-1}\right)\end{array}$ & $\begin{array}{l}\mathrm{eqCaCO}_{3} \\
(\%)\end{array}$ & $\begin{array}{l}\mathrm{OC} \\
(\%)\end{array}$ & $\mathrm{TN}(\%)$ & $\begin{array}{l}\mathrm{CEC} \\
(\mathrm{cmol} \\
\left.(+) \mathrm{kg}^{-1}\right)\end{array}$ & $\begin{array}{l}\text { Sand } \\
(\%)\end{array}$ & $\begin{array}{l}\text { Silt } \\
(\%)\end{array}$ & $\begin{array}{l}\mathrm{Clay} \\
(\%)\end{array}$ \\
\hline Plot 1 & $7.7(<0.1)$ & $7.4(<0.1)$ & $4.8(1.6)$ & $27(2)$ & $0.68(0.01)$ & $0.07(0.01)$ & $7.5(0.4)$ & $43(3)$ & $35(2)$ & $22(1)$ \\
Plot 2 & $8.2(<0.1)$ & $7.6(<0.1)$ & $3.5(1.1)$ & $29(3)$ & $0.79(0.16)$ & $0.08(0.02)$ & $9.3(1.2)$ & $30(1)$ & $44(1)$ & $26(1)$ \\
Plot 3 & $8.2(<0.1)$ & $7.6(<0.1)$ & $4.0(0.8)$ & $28(3)$ & $0.50(0.13)$ & $0.07(0.01)$ & $7.6(0.7)$ & $37(3)$ & $41(3)$ & $22(1)$ \\
Plot 4 & $8.0(<0.1)$ & $7.5(<0.1)$ & $4.1(0.6)$ & $42(2)$ & $0.74(0.19)$ & $0.10(0.01)$ & $7.6(1.3)$ & $31(1)$ & $48(2)$ & $21(1)$ \\
$\begin{array}{c}\text { Agricultural soil } \\
\text { in the nearby }\end{array}$ & 8.3 & 7.5 & 0.6 & 26 & 0.72 & 0.05 & 12 & 42 & 29 & 29 \\
$\begin{array}{c}\text { Agricultural soil } \\
\text { in the nearby }\end{array}$ & 8.3 & 7.6 & 1.11 & 45 & 0.75 & 0.06 & 9.4 & 30 & 44 & 36 \\
\hline
\end{tabular}

Values in brackets are standard deviation $(N=9)$

$\mathrm{pH}$ in 1:1 water:soil and $1 \mathrm{~N} \mathrm{KCl}$ :soil ratios $\mathrm{EC}$ electrical conductivity of the saturated extract, eqCaCO$\%$ equivalent calcium carbonate, $O C$ organic carbon, $T N$ total nitrogen, $C E C$ cation exchange capacity

${ }^{\mathrm{a}}$ Conesa (2003)

values cannot be used as reference levels for the mining district area because of its different geological basis. Some studies in agricultural areas close to the mining area (Conesa 2003) have shown metal contents of 77-160 mg kg-1 Cu, 28-150 mg kg-1 $\mathrm{Pb}$, and 93$400 \mathrm{mg} \mathrm{kg}^{-1} \mathrm{Zn}$. In this sense, samples from our study (Table 2) had higher concentration of $\mathrm{Pb}$ (all samples were higher than $200 \mathrm{mg} \mathrm{kg}^{-1}$ ) and $\mathrm{Zn}$ (samples from plots 1 and 2 were higher than $400 \mathrm{mg} \mathrm{kg}^{-1}$ ).

DTPA extractable $\mathrm{Cu}$ had similar percentages in the four plots $(8.5-11 \%)$. In relation to $\mathrm{Pb}$, more than $10 \%$ of the total content is extractable by DTPA in plots 2,3 , and 4 . For $\mathrm{Zn}$, this also occurred in plots 2 and 4.

\subsubsection{Soil Transects}

The transect 1 was done crossing the tailing from its plateau (point 1) till the base of the slope (point 7; Fig. 2). The $\mathrm{pH}$ values of soil samples from this transect (data not shown) were between 7.5 and 8.6. Higher differences occurred in electrical conductivity (from $2.2 \mathrm{dS} \mathrm{m}^{-1}$ at point 7 to $11.7 \mathrm{dS} \mathrm{m}^{-1}$ at point 3). The percentages of equivalent calcium carbonate were higher than $250 \mathrm{~g} \mathrm{CaCO}_{3} \mathrm{~kg}^{-1}$ soil in all the samples, except in point 7 , where $100 \mathrm{~g} \mathrm{CaCO}_{3} \mathrm{~kg}^{-1}$ soil was reached. Total $\mathrm{Cu}$ showed to be below $20 \mathrm{mg} \mathrm{kg}^{-1}$ in all the samples except in points $4\left(27 \mathrm{mg} \mathrm{kg}^{-1}\right)$ and 7 $\left(83 \mathrm{gkg}^{-1}\right)$. Point 7 showed the highest concentrations of $\mathrm{Zn}$ and $\mathrm{Pb}\left(5,800 \mathrm{mg} \mathrm{kg}^{-1}\right.$ and $4,500 \mathrm{mg} \mathrm{kg}^{-1}$, respectively). The latter is placed on the base of the slope, where erosion has removed the upper capping layer and mining wastes have formed bare spots without vegetation.

The transect 2, which was parallel to the base of the tailing, showed higher metal concentrations in relation to the transect 1 indicating that the slopes of the tailing were critical points where the capping layer had been eroded. The $\mathrm{pH}$ values varied between 7.5

Table $2 \mathrm{~Pb}, \mathrm{Zn}$, and $\mathrm{Cu}$ in total and DTPA-extractable fractions

\begin{tabular}{|c|c|c|c|c|c|c|}
\hline \multirow[t]{2}{*}{ Plot } & \multicolumn{2}{|l|}{$\mathrm{Cu}$} & \multicolumn{2}{|l|}{$\mathrm{Pb}$} & \multicolumn{2}{|l|}{$\mathrm{Zn}$} \\
\hline & Total & DPTA extractable & Total & DPTA extractable & Total & DPTA extractable \\
\hline Plot 1 & $14 \pm 3.8(8.0-19)$ & $1.2 \pm 0.2(1.1-1.6)$ & $430 \pm 230(300-770)$ & $18 \pm 4.3(14-25)$ & $920 \pm 240(540-1,400)$ & $46 \pm 13(34-76)$ \\
\hline Plot 2 & $21 \pm 2.2(18-25)$ & $2.5 \pm 0.5(2.0-3.6)$ & $530 \pm 200(400-1,060)$ & $78 \pm 5.2(71-85)$ & $730 \pm 65(640-860)$ & $74 \pm 5.2(67-82)$ \\
\hline Plot 3 & $14 \pm 0.8(12-15)$ & $1.2 \pm 0.12(1.0-1.4)$ & $180 \pm 18(160-200)$ & $22 \pm 3.8(16-27)$ & $250 \pm 49(210-360)$ & $19 \pm 2.5(16-22)$ \\
\hline Plot 4 & $15 \pm 1.1(13-17)$ & $1.6 \pm 0.3(1.4-2.0)$ & $390 \pm 170(290-840)$ & $72 \pm 6.6(63-78)$ & $330 \pm 39(290-420)$ & $47 \pm 8.0(40-67)$ \\
\hline
\end{tabular}

The values are means \pm standard deviation; minimum and maximum in brackets. $N=9$ 
and 8.6. Points 4, 5, and 6 had $\mathrm{Cu}$ concentrations between 20 and $25 \mathrm{mg} \mathrm{kg}^{-1}$. The rest of the points were below $20 \mathrm{mg} \mathrm{kg}^{-1} \mathrm{Cu}$. Points 3, 4, 5, and 6 showed concentrations of around $550-1,000 \mathrm{mg} \mathrm{kg}^{-1} \mathrm{~Pb}$ and $1,000-1,500 \mathrm{mg} \mathrm{kg}^{-1} \mathrm{Zn}$.

\subsection{Plant Analyses}

Figure 3 shows metal concentration in leaves (Fig. 3a) and roots (Fig. 3b) after transplant (first

$\mathrm{Cu}$

a) Leaves

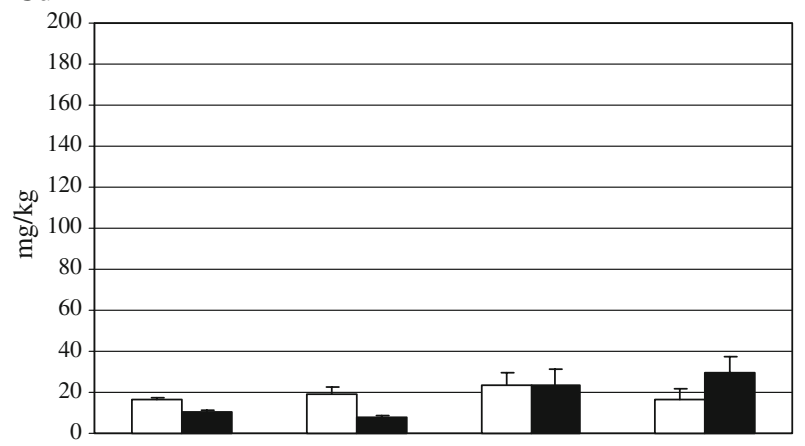

$\mathbf{P b}$

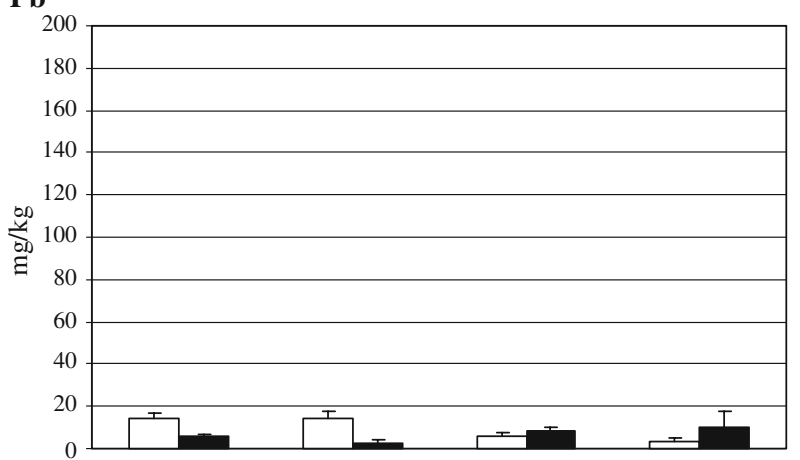

Zn

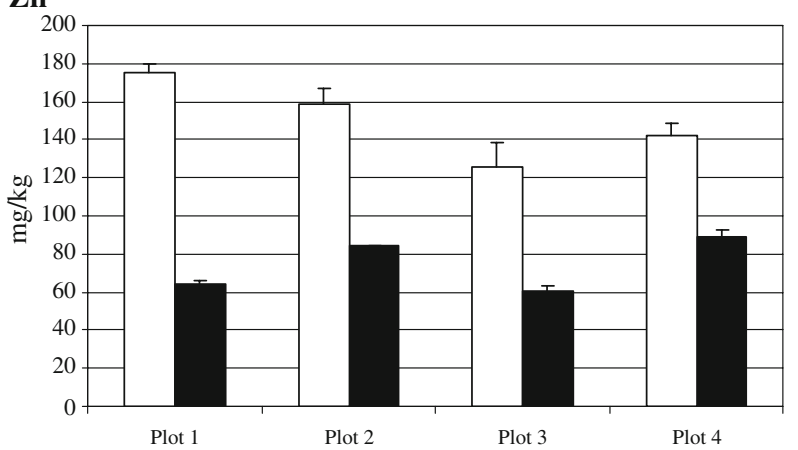

week) and during harvest (fifth week). After transplant, $\mathrm{Cu}$ and $\mathrm{Pb}$ concentrations were higher in roots in comparison to leaves except for $\mathrm{Zn}$, where the opposite occurred. In the harvest, also $\mathrm{Zn}$ concentrations were higher in roots in relation to leaves. It has been shown that seedlings have less strict rootto-shoot barriers for metals compared to as adult plants (Gasic and Korban 2006); therefore, the $\mathrm{Zn}$ concentrations in leaves of seedlings is expected to be higher than in adult plants.

\section{b) Roots}
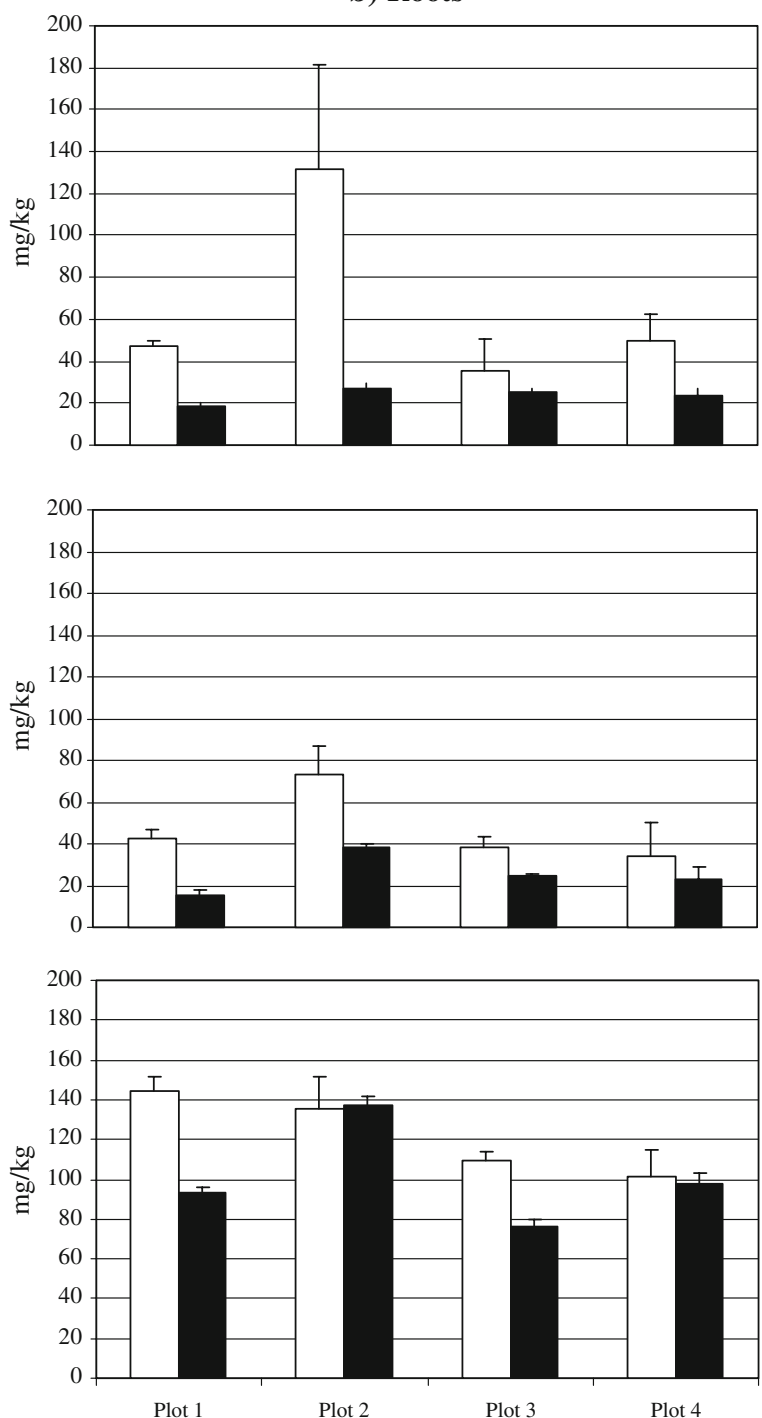

$\square$ Transplant $\square$ Harvest

Fig. 3 Metal concentrations in lettuce leaves (a) and roots (b). White columns are analyses after transplant (1 week) and black columns are analyses during harvest ( 5 weeks). Black bars on columns are standard error. $4<N<6$ 
In general, metal concentrations in leaves (Fig. 3a) decreased in the harvest in relation to transplant, except for $\mathrm{Cu}$ and $\mathrm{Pb}$ in plots 3 and 4 . At the plot 4 , these differences in concentration reached almost the double in relation to $\mathrm{Pb}$ (from $4 \mathrm{mg} \mathrm{kg}^{-1}$ in transplant to $10 \mathrm{mg} \mathrm{kg}^{-1}$ in harvest) and $\mathrm{Cu}$ (from $17 \mathrm{mg} \mathrm{kg}^{-1}$ in transplant to $28 \mathrm{mg} \mathrm{kg}^{-1}$ in harvest). That is in agreement with the DTPA-extracted results (Table 2) which showed for the plot 4 the highest percentage of DTPA-extractable $\mathrm{Pb}$ (18\% of the total concentration) and $\mathrm{Cu}(10 \%)$.

Cobb et al. (2000) obtained lower Zn uptake in lettuce plants (up to $25.5 \mathrm{mg} \mathrm{kg}^{-1}$ in leaves; up to $33.8 \mathrm{mg} \mathrm{kg}^{-1}$ in roots) growing in soils amended with mining wastes which contained higher metal concentrations (up to $10,500 \mathrm{mg} \mathrm{kg}^{-1} \mathrm{~Pb}$; up to $5,250 \mathrm{mg} \mathrm{kg}^{-1} \mathrm{Zn}$ ). However, the same authors showed much higher $\mathrm{Pb}$ uptake in leaves (from 227 to $919 \mathrm{mg} \mathrm{kg}^{-1}$ in leaves) in relation to our study. This shows clearly the need of specific site metal uptake assessment in order to manage correctly food safety issues.

The European Union (European Communities Council 2001) settled a maximum of $0.3 \mathrm{mg} \mathrm{kg}-1$ $\mathrm{Pb}$ (fresh weigh) for leaf vegetables. For our study, $\mathrm{Pb}$ concentration in fresh weight (data not shown) varied from 0.1 to $0.3 \mathrm{mg} \mathrm{kg}^{-1}$, and therefore, it was within the legal requirements. The lettuce leaves from our experiment had maximums (in relation to fresh weight) of $4.6 \mathrm{mg} \mathrm{kg}^{-1} \mathrm{Zn}$ and $1.5 \mathrm{mg} \mathrm{kg}^{-1} \mathrm{Cu}$. If consumed as a major part of the diet (lettuce is a traditional ingredient of the Mediterranean diet), the tolerable upper intake levels for adults $\left(40 \mathrm{mg}\right.$ day $^{-1}$ $\mathrm{Zn}$ and $10 \mathrm{mg}$ day $^{-1} \mathrm{Cu}$; NAS 2001) would not be reasonable to reach.

It has been long discussed in literature about the risk of cultivating crops for humans in soils with high contents of metals (Alloway et al. 1998). In the last years, biofortification has been in much attention in relation to trace elements in crops. Biofortification aims to increase the concentration of essential trace elements in crops to improve human health and agricultural productivity (White and Broadley 2005). Micronutrients as $\mathrm{Fe}$ and $\mathrm{Zn}$ are usually in deficient status in many diets (Branca and Ferrari 2002). Physiologically accumulated micronutrients in plants provide a more feasible assimilated source of micro- nutrients than in the form of inorganic supplements to the diet (White and Broadley 2005).

Inorganic supplies of $\mathrm{Zn}$ in diets may create a problem if there is no balance with another essential elements (it may affect copper assimilation). Some reports have shown some diseases when ratios $\mathrm{Zn} / \mathrm{Cu}$ (milligrams per day/milligrams per day) are over 18 (Maret and Sandstead 2006). In our case, lettuce leaves had eight times more $\mathrm{Zn}$ in relation to $\mathrm{Cu}$, and therefore, $\mathrm{Cu}$ assimilation is not expected to be affected. Lettuces have been already investigated for biofortification with promising results in relation to iodine (Blasco et al. 2008). However, due to the narrow limits between deficiency and toxicity in terms of trace element concentration, an intense monitoring has to be performed in these crop areas (including analyses and sampling with strong statistical basis). These aspects may hinder the social acceptance or the economical feasibility of these productive areas.

\section{Conclusions}

Former capped mine tailings remain as an important environmental issue. We investigated lettuce crops close to a capped mine tailing. Results showed that the former capping materials of the tailing have been eroded in some areas along the base of the tailing and that high metal concentrations spots may be exposed to wind and water erosion. As a consequence, there is high risk of heavy metal transfer to the soil of the nearby crop land. Capping actions should be checked from time to time in the tailings in order to prevent the exposition of the tailing materials to the soil surface or root zone (e.g., adding new layers of soil, establishment of more suitable vegetation with higher root system).

Soil analyses showed high concentrations of metals $(\mathrm{Pb}$ and $\mathrm{Zn})$ in some points of the crop area. Lettuce leaves accumulated $\mathrm{Pb}$ below the legal standards. In order to preserve in future the food safety, some monitoring programs should be performed in plants.

Acknowledgments We want to thank Dr. Ripolles for his valuable comments and Fundación Séneca de la Comunidad Autónoma de Murcia for its financial support. Also, we want to thank Willy Manfredo for his comments in relation to English typing. 


\section{References}

Alloway, B. J., Thornton, I., Smart, G. A., Sherlock, J. C., \& Quinn, M. J. (1998). Metal availability. Science of the Total Environment, 75(1), 41-69.

Blasco, B., Rios, J. J., Cervilla, L. M., Sánchez-Rodríguez, E., Ruiz, J. M., \& Romero, L. (2008). Iodine biofortification and antioxidant capacity of lettuce: Potential benefits for cultivation and human health. Annals of Applied Biology, 152(3), 289-299.

Branca, F., \& Ferrari, M. (2002). Impact of micronutrient deficiencies on growth: The stunting syndrome. Annuals of Nutrition and Metabolism, 46, 8-17.

Chapman, H. D. (1965). Cation exchange capacity. In C. A. Black (Ed.), Methods of soils analysis (pp. 891-901). Madison: American Society of Agronomy.

Cobb, G. P., Sands, K., Waters, M., Wixson, B. G., \& DorwardKing, E. (2000). Accumulation of heavy metals by vegetables grown in mine wastes. Environmental Toxicology and Chemistry, 19(3), 600-607.

Conesa, H. M. (2003). Informe Agronómico sobre la finca de "Las Jacobas". Cartagena, Spain: Universidad Politécnica de Cartagena. Technical report.

Conesa, H. M., Faz, Á., \& Arnaldos, R. (2006). Heavy metal accumulation and tolerance in plants from mine tailings of the semiarid Cartagena-La Union mining district (SE Spain). Science of the Total Environment, 366(1), 1-11.

Conesa, H. M., Moradi, A. B., Robinson, B. H., Kuhne, G., Lehmann, E., \& Schulin, R. (2009). Response of native grasses and Cicer arietinum to soil polluted with mining wastes: Implications for the management of land adjacent to mine sites. Environmental and Experimental Botany, 65 (2-3), 198-204.

Duchaufour, Ph. (1970). Précis de Pedologie. París: Masson y Cie.

European Communities. (2001) Commission Regulation 466/ 2001 setting maximum levels for certain contaminants in foodstuffs. Off. J. Eur. Commun. L77, 16/03/01, 1-13.

Ernst, W. H. O. (1996). Bioavailability of heavy metals and decontamination of soils by plants. Applied Geochemistry, 11(1-2), 163-167.
Gasic, K., \& Korban, S. S. (2006). Heavy metal stress. In K. V. Madhava Rao, A. S. Raghavendra \& K. Janardhan Reddy (Eds.), Physiology and molecular biology of stress tolerance in plants (pp. 219-254). New York: Springer.

Lee, J.-S., \& Chon, H. T. (2003). Exposure assessment of heavy metals on abandoned metal mine areas by ingestion of soil, crop plant and groundwater. Journal de Physique IV, 107, 757-760.

Leita, L., Mondini, C., De Nobili, M., Simoni, A., \& Sequi, P. (1998). Heavy metal content in xylem sap (Vitis vinifera) from mining and smelting areas. Environmental Monitoring and Assessment, 50(2), 189-200.

Lindsay, W. L., \& Norvell, W. A. (1978). Development of a DTPA soil test for zinc, iron, manganese and copper. Soil Science Society of America Journal, 42(3), 421-428.

Maret, W., \& Sandstead, H. H. (2006). Zinc requirements and the risks and benefits of zinc supplementation. Journal of Trace Elements in Medicine and Biology, 20 (1), 3-18.

Martínez-Orozco, J. M., Valero-Huete, F., \& González-Alonso, S. (1993). Environmental problems and proposals to reclaim the areas affected by mining exploitations in the Cartagena mountains (southeast Spain). Landscape and Urban Planning, 23(3-4), 195-207.

Martínez-Sánchez, M. J., \& Pérez-Sirvent, C. (2007). Niveles de fondo y niveles genéricos de referencia de metales pesados en suelos de la Región de Murcia. Murcia: Universidad de Murcia, Región de Murcia, Consejería de Desrrollo Sostenible y Ordenación del Territorio.

NAS (National Academy of Sciences). (2001). Dietary reference intakes for vitamin A, vitamin $\mathrm{K}$, arsenic, boron, chromium, copper, iodine, iron, manganese, molybdenum, nickel, silicon, vanadium, and zinc. National Academy of Sciences, Institute of Medicine, Food and Nutrition Board, USA, http://www.nap.edu.

Salomons, W. (1995). Environmental impact of metals derived from mining activities: processes, predictions, prevention. Journal of Geochemical Exploration, 52(1-2), 5-23.

White, P. J., \& Broadley, M. R. (2005). Biofortifying crops with essential mineral elements. Trends in Plant Science, 10 (12), 586-593. 